\title{
MINERAL RESOURCE POTENTIAL OP THE RUBICON ROADLESS AREA, PLACER AND EL DORADO COUNTIES, CALIFORNIA
}

\section{SUMMARY REPORT}

By

David S. Harwood

U.S. Geological Survey

and

Eric E. Cather and Douglas P. Scott

U.S. Bureau of Mines

\section{STUDIES RELATED TO WILDERNESS}

Under the provisions of the Wilderness Act (Public Law 88-577, September 3, 1964) and the Joint Conference Report on Senate Bill 4, 88th Congress, the U.S. Geological Survey and the U.S. Bureau of Mines have been conducting mineral surveys of wilderness and primitive areas. Areas of ficially designated as "wilderness," "wild," or "canoe" when the act was passed were incorporated into the National Wilderness Preservation system, and some of them are presently being studied. The act provided that areas under consideration for wilderness designation should be studied for suitability for incorporation into the Wilderness System. The mineral surveys constitute one aspect of the suitability studies. The act directs that the results of such surveys are to made available to the public and be submitted to the President and the Congress. This report discusses the results of a mineral survey of the Rubicon Roadless Area (5-026), Tahoe and El Dorado National Forests, Placer and El Dorado counties, California. The area was classified as a further planning area during the Second Roadless Area Review and Evaluation (RARE II) by the U.S. Forest Service, January 1979.

\section{SUMMARY}

A mineral resource survey of the Rubicon Roadless Area, encompassing $8.0 \mathrm{mi}^{2}\left(20.7 \mathrm{~km}^{2}\right)$ in the Tahoe and El Dorado National Forests, was conducted in 1981 and 1982. The mineral resource potential of the area was evaluated from geologic and geochemical studies by the U.S. Geological Survey, and from the examination of published and unpublished records of mining prospects and field examination of mines, prospects, placer deposits, and mineralized rocks by the U.S. Bureau of Mines.

These investigations indicate that the roadless area has a low potential for mineral resources. Gold was found in samples taken from the abandoned Pigeon Roost mine adjacent to the area and in a stream-sediment sample collected downstream from the mine. These deposits are small and low grade, but they may be of interest to weekend prospectors.

Deposits of glacial outwash and modern alluvium are generally too small and too bouldery to be of commercial value as construction materials. No potential for oil, gas, coal, or geothermal resources was identified.

\section{INTRODUCTION}

\section{Location and access}

The Rubicon Roadless Area is located on the lower reaches of the Rubicon River, a major tributary of the Middle Fork of the American River that drains the western slope of the Sierra Nevada in eastern California. Along most of its course, the Rubicon River forms the boundary between Placer and El Dorado Counties and the Tahoe and El Dorado National Forests. The study area is small compared to many established and proposed Sierran wilderness areas encompassing only 5,100 acres $\left(8.0 \mathrm{mi}^{2}, 20.6 \mathrm{~km}^{2}\right)$. From an elevation of $3,350 \mathrm{ft}(1,020 \mathrm{~m})$ at its east boundary, the study area follows the arcuate course of the Rubicon River westward for about $8.0 \mathrm{mi}(12.9 \mathrm{~km})$ to an elevation of $2,260 \mathrm{ft}(690 \mathrm{~m})$. Over this distance, the study area is generally confined to the steep walls of the river canyon where local relief is as much as $1,500 \mathrm{ft}(457 \mathrm{~m})$; maximum elevation in the area is about $4,800 \mathrm{ft}(1,464 \mathrm{~m})$.

Because of its proximity to Placerville, which is $21 \mathrm{mi}$ $(34 \mathrm{~km})$ to the southwest, and Sacramento, which is $37 \mathrm{mi}(60$ $\mathrm{km})$ to the west, the study area presently is used extensively as a back-country retreat for outdoor recreation. Access to the area is provided by a hard-surfaced road that extends eastward from Georgetown, Calif., toward Uncle Tom's cabin (fig. 1). The hard-surfaced road crosses the Rubicon at the east boundary of the study area and traverses the north wall of the river canyon and ridge between the Rubicon and the Middle Fork of the American River to the north. Several graveled roads spur off from the hard-surfaced road and provide access to the rim of the canyon in the western part of the area. Although no clearly marked trails enter the study area, hiking is relatively easy down the wooded but brush-free canyon walls and along the Rubicon River in the eastern part of the area. The U.S. Forest Service maintains a campground at Stumpy Meadow Lake.

\section{Present and previous studies}

Early geologic work in the area was done by Lindgren and Turner (1894) as part of their study of the Placerville quadrangle. Strand and Koenig (1966) essentially incorporated this early work, with little modification, into their compilation of the Sacramento sheet of the $1: 250,000$-scale geologic map of California as did Wagner and others (1981) in their recent revision of that map.

Geologic and geochemical studies, related specifically to evaluating the mineral resource potential of the roadless area, were conducted by the U.S. Geological Survey in 1982. Bedrock, surficial glacial deposits, and recent alluvium were examined for concentrations of economic minerals and construction materials and a detailed geologic and geochemical map of this part of the Sierra Nevada resulted from those 
studies (Harwood, 1983a).

In 1981, the U.S. Bureau of Mines examined published and unpublished records of Placer and El Dorado Counties to determine mining claims and lease locations in and adjacent to the study area. Fieldwork was also conducted to find and sample claimed areas, prospects, mines, and mineralized areas. During this study nine panned-concentrate samples were taken from the modern alluvium along the Rubicon River and two samples were taken from Tertiary placer gravel exposed at the abandoned Pigeon Roost mine. The Tertiary gravel samples were further concentrated in the laboratory and gold was picked from the concentrate, amalgamated, and weighed. In addition, two chip samples were collected from bedrock exposures; one from a limonitestained shear zone and the other from a pegmatite dike. The chip samples were crushed, pulverized, thoroughly mixed, split, and fire assayed for gold and silver. They were also

Analyzed for $\mathbf{4 0}$ elements by standard semiquantitative spectrographic analysis. In addition, the pegmatite sample was analyzed for lithium dioxide and beryllium oxide by atomic adsorption. During fieldwork, the area was checked with a scintillometer for anomalous concentrations of radioactive elements.

\section{GBOLOGY AND GBOCHEMISTRY PERTAINING TO MINERAL RESOURCB ASSESSMENT}

Geology

Geologic setting

The Rubicon Roadless Area is located in the northcentral part of the Sierra Nevada, a faulted and westwardtilted mountain range that extends half the length of eastern California. The eastern slope of the range is steep, reflecting youthful topography controlled by an active fault system along which the range has been uplifted. The western slope of the range is relatively gentle, but deeply incised by major river systems that drain to the Great Valley of California. Tertiary volcanic rocks, erupted from numerous vents on and near the eastern range-front fault system, cap the ridges between the major rivers in this part of the western slope of the range. Along much of the northern Sierra Nevada, the Tertiary volcanic rocks are underlain by Tertiary gravel deposits of variable thickness, that have produced significant amounts of gold in the past. In the Rubicon Roadless Area, however, Tertiary gravel is absent beneath the volcanic rocks except for a small deposit exposed on the walls of the abandoned Pigeon Roost mine. Unconsolidated glacial deposits, representing bouldery outwash from Pleistocene glaciers that capped the range to the east, are plastered on the canyon walls in the eastern part of the study area.

Metamorphic rocks

The oldest rocks in the study area are quartzite, pelite, calcareous quartzite, calc-silicate rocks and thin layers of sandy marble assigned to the Shoo Fly Complex of Ordovician(?) to Devonian(?) age (Harwood, 1983b). To the north and west, the Shoo Fly locally contains abundant goldbearing quartz veins that define a zone of gold and silver mineralization known as the Mother Lode district. Few quartz veins occur in the Shoo Fly Complex in the study area and no bedrock samples contained detectable gold or silver.

\section{Intrusive rocks}

The metamorphic rocks are intruded by three small plutons of hornblende quartz diorite and granodiorite that are related to the Sierra Nevada batholith, which constitutes most of the bedrock exposed southeast of the study area. No significant zones of alteration or mineralization were found in the intrusive rocks in the study area.

Tertiary volcanic rocks

The metamorphic and intrusive igneous rocks are unconformably capped by local thin deposits of rhyolite tuff on the north rim of the Rubicon River canyon and by extensive deposits of andesitic lahars (volcanic mudflows) on the interfluves north and south of the study area. No mineralized areas were found in the Tertiary volcanic rocks. Beneath the Tertiary volcanic rocks there is a thin, localized deposit of Tertiary gravel exposed in the abandoned workings of the Pigeon Roost mine. Although minor amounts of gold were found in this Tertiary gravel, the gold values were too erratic and the deposit too small for it to be considered a resource.

\section{Quaternary glacial deposits}

Unconsolidated glacial deposits that occur in the eastern part of the study area contain no detectable amounts of gold or other economic minerals. The deposits are too small, too remote, and too bouldery to constitute commercial quantities of construction materials.

\section{Geochemistry}

A geochemical study of panned concentrates taken from modern alluvium along the Rubicon River and its major tributaries in the study area (Harwood, 1983a) and a comparable study by the U.S. Bureau of Mines failed to identify any potentially favorable mineralized areas. Trace amounts of gold were identified in the Tertiary gravel deposit at the abandoned Pigeon Roost mine and in a panned concentrate collected downstream from the mine. The deposits in which the gold was found are too small to constitute a resource, but they may be of interest to weekend prospectors.

Minor lead and copper anomalies were identified in stream-sediment samples collected from the hornblende quartz diorite pluton in the eastern part of the study area. No sulfide-bearing veins or mineralized zones were found in the quartz diorite, and it is concluded that the lead and copper, detected in the geochemical survey, are widely disseminated in the intrusive rocks.

\section{PROSPECTS AND MINERALIZED AREAS}

Only one prospect is located in the immediate vicinity of the Rubicon Roadless Area. On the north wall of the Rubicon River canyon near the western part of the study area, a small Tertiary river channel containing coarse gravel was prospected at the Pigeon Roost mine. The property contains an open, slumped trench about $500 \mathrm{ft}(152 \mathrm{~m})$ long, $100 \mathrm{ft}(30 \mathrm{~m})$ wide, and $15 \mathrm{ft}(4.6 \mathrm{~m})$ deep, which appears to represent most of the original gravel deposit. Two samples of gravel exposed on the walls of the trench contained gold

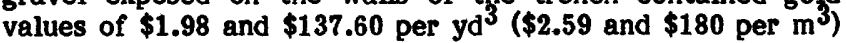
assuming $\$ 400$ per troy oz for gold. No production records could be found for the Pigeon Roost mine.

\section{ASSESSMENT OF MINERAL RESOURCE POTBNTIAL}

Investigations by the U.S. Bureau of Mines and the U.S. Geological Survey indicate that the study area has a low mineral resource potential. Although the area is underlain by rocks that have hosted deposits of gold and silver to the west and northwest, no similar deposits have been found in the study area. Geochemical analyses of stream-sediment samples indicate only minor amounts of gold at the abandoned Pigeon Roost mine and in the creek below the mine. No significant concentrations of base-metal sulfides were found.

No potential for oil, gas, geothermal, or coal resources was identified in the area.

\section{REFERENCES CTTED}

Harwood, D. S., 1983a, Geologic and geochemical maps of the Rubicon Roadless Area, Placer and $\mathrm{El}$ Dorado Counties, California: U.S. Geological Survey Miscellaneous Field Investigations Map MF-1501-A, scale $1: 24,000$.

$1983 \mathrm{~b}$, Stratigraphy of upper Paleozoic volcanic rocks and regional unconformities in part of the northern Sierra terrane, California: Geological Society of America Bulletin [in press]. 
Lindgren, Waldemar, and Turner, H. W., 1894, Placerville Quadrangle, California, folio 3 of Geologic atlas of the United States: U.S. Geological Survey, scale $1: 125,000$.

Strand, R. G., and Koenig, J. B., 1966, Sacramento sheet, Geologic map of California (Olaf P. Jenkins edition): California Division of Mines and Geology, scale $1: 250,000$.
Wagner, D. L., Jennings, C. W., Bedrossian, T. L., and Bortugno, E. J., 1981, Geologic map of the Sacramento quadrangle, California: California Division of Mines and Geology Regional Geologic Map Series, Map 1A (geology), scale, 1:250,000. 


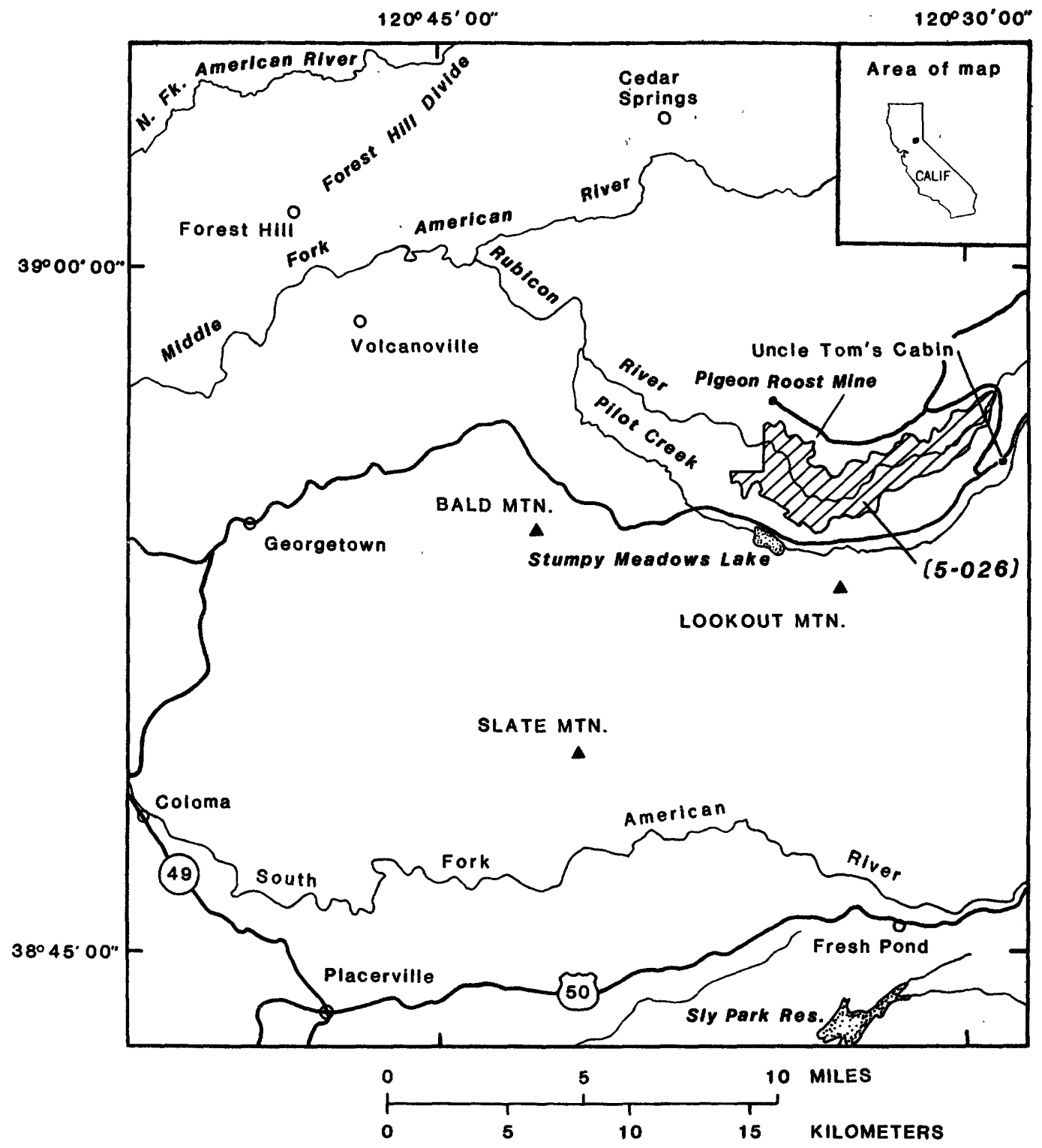

Figure 1.--Location of the Rubicon Roadless Area (5-026) and the abandoned Pigeon Roost mine. 